\title{
Epidemiologic characterization of bovine tuberculosis in the State of Rondônia, Brazil
}

\author{
Caracterização epidemiológica da tuberculose bovina no \\ Estado de Rondônia, Brasil
}

\begin{abstract}
Fabiano Benitez Vendrame'; Marcos Amaku²; Fernando Ferreira²; Evelise Oliveira Telles $^{2}$; José Henrique Hildebrand Grisi-Filho²; Vitor Salvador Picão Gonçalves ${ }^{3}$; Marcos Bryan Heinemann²; José Soares Ferreira Neto²; Ricardo Augusto Dias²*
\end{abstract}

\begin{abstract}
A cross sectional study was performed between June 2009 and March 2010 to determine the situation of bovine tuberculosis (bTB) in Rondônia. The state was divided into three regions and, in each of them, 300 farms with reproductive activity were randomly chosen and considered as primary sample units. In the selected farms, an epidemiologic questionnaire was applied. A fixed number of bovine females older than two years of age was randomly selected and tested through comparative cervical tuberculin test. Considering the State of Rondônia, the apparent prevalence of bTB positive farms was $2.3 \%$ (95\% $\mathrm{CI}=1.5-3.5 \%)$. The prevalence in the regions varied from $1.7 \%(95 \% \mathrm{CI}=0.7-4 \%)$ to $3 \%(95 \% \mathrm{CI}=$ 1.6-5.7\%). The apparent prevalence of bTB positive animals in the State of Rondônia was $0.12 \%(95 \%$ $\mathrm{CI}=0.06-0.25 \%)$ and varied from $0.08 \%(95 \% \mathrm{CI}=0.04-0.18 \%)$ to $0.15 \%(95 \% \mathrm{CI}=0.07-0.33 \%)$ in the regions. The risk factor associated to tuberculosis in the State of Rondônia was the acquisition of animals (OR $=7.1 ; 95 \% \mathrm{CI}=1.6-31.1)$. The State of Rondônia should implement a surveillance system to detect bTB-infected herds to certify them as bTB-free. Moreover, an efficient health education program to inform farmers to test replacement animals for bTB prior to introduction in their herds should also be implemented.
\end{abstract}

Key words: Bovine. Brazil. Prevalence. Risk factor. Rondônia. Tuberculosis.

\section{Resumo}

Entre junho de 2009 e março de 2010 foi realizado um estudo transversal para determinar a situação da tuberculose bovina (BTB) em Rondônia. O estado foi dividido em três regiões e, em cada uma delas 300 propriedades com atividade reprodutiva foram sorteadas e consideradas como unidades amostrais primárias. Nas fazendas selecionadas, foi aplicado um questionário epidemiológico. Um número fixo de fêmeas bovinas com idade superior a dois anos de idade foram selecionada aleatoriamente e testadas através do teste tuberculínico cervical comparativo. Considerando-se o Estado de Rondônia, a prevalência aparente de focos foi de $2,3 \%$ (IC $95 \%=1,5-3,5 \%$ ). A prevalência nas regiões variou de $1,7 \%(95 \%$ IC $=0,7-4 \%)$ a $3 \%(95 \% \mathrm{CI}=1,6-5,7 \%)$. A prevalência aparente de animais positivos no Estado foi de $0,12 \%$ (IC $95 \%=0,06-0,25 \%$ ) e variou de $0,08 \%$ (IC $95 \%=0,04-0,18 \%$ ) a $0,15 \%$ (IC $95 \%=0.07-0,33 \%)$ nas regiões. $\mathrm{O}$ fator de risco associado à tuberculose no Estado de Rondônia

\footnotetext{
1 Discente. Agência de Defesa Sanitária Agrosilvopastoril do Estado de Rondônia, Porto Velho, RO, Brasil. nelorebr@hotmail.com.

2 Profs., Faculdade de Medicina Veterinária e Zootecnia, Universidade de São Paulo, USP, São Paulo, SP, Brasil. E-mail Brasil. E-mail: amaku@vps.fmvz.usp.br; fernando@vps.fmvz.usp.br; bufalo@usp.br; grisi@vps.fmvz.usp.br; marcosbryan@usp.br; jsoares@vps.fmvz.usp.br; dias@vps.fmvz.usp.br

3 Prof., Faculdade de Agronomia e Medicina Veterinária, Universidade de Brasília, UnB, Brasília, DF, Brasil. E-mail: vitorspg@ unb.br

* Author for correspondence
} 
foi a aquisição de animais $(\mathrm{OR}=7,1$; IC95\% = 1,6-31,1). O Estado deve implementar um sistema de vigilância para detectar e sanear focos. Além disso, o estado deverá implementar um eficiente programa de educação para informar aos produtores a necessidade de testar os animais de reposição para tuberculose antes de introduzi-los em seus rebanhos.

Palavras-chave: Bovino. Brasil. Prevalência. Fator de risco. Rondônia. Tuberculose.

\section{Introduction}

Bovine tuberculosis (bTB) is a chronic zoonotic disease caused by Mycobacterium bovis that, in addition to cattle, affects small ruminants, humans, and other domestic and wild animals. These bacteria cause a chronic granulomatous caseous-necrotizing inflammatory process in many organs, depending on the route of entry. The main route of entry is inhalation, causing primary lesions in lungs and accessory lymph nodes, but bacteria can also be ingested, causing primary lesions in the mesenteric lymph nodes (DOMINGO et al., 2014). Apart from the risk to public health, the disease causes economic losses to cattle industry (ZINSSTAG et al., 2006), especially in Africa, Central and South America, and Asia (OIE, 2015). Usually, the disease is endemic and widespread in large territories connected by commercial relations, especially animal trade (GILBERT et al., 2005).

In 2001, the Brazilian Ministry of Agriculture, Livestock, and Food Supply (MAPA) has launched the National Program for the Control and Eradication of Animal Brucellosis and Tuberculosis (PNCEBT), aiming at the reduction of the negative impacts of bovine brucellosis and tuberculosis on human health and the promotion of the competitiveness of the national livestock industry (MAPA, 2006). The control measures of PNCEBT include movement control of reproducing animals and certification of tuberculosis-free farms (MAPA, 2006). These activities, such as diagnostic tests and veterinary services, are paid by farmers. The official veterinary service is responsible only for auditing the entire system.

In Brazil, recent studies carried out in 12 States, which hold $69 \%$ of the Brazilian cattle population, showed a prevalence of tuberculosis-infected herds between $0.36 \%$ in the Federal District and 9.0\% in São Paulo state (BAHIENSE et al., 2016; BARBIERI et al., 2016; DIAS et al., 2016; GALVIS et al., 2016; GUEDES et al., 2016; LIMA et al., 2016; NÉSPOLI et al., 2016; QUEIROZ et al., 2016; RIBEIRO et al., 2016; ROCHA et al., 2016; SILVA et al., 2016; VELOSO et al., 2016).

No state survey of bovine tuberculosis has ever been done in the State of Rondônia; therefore, the present study aims to estimate the prevalence of bovine tuberculosis and risk factors in the State, in order to allow the management of the animal health policy.

\section{Materials and Methods}

\section{Sample design}

The present study was planned by the Brazilian Ministry of Agriculture, Livestock, and Food Supply (MAPA), the University of São Paulo (USP), the University of Brasília (UnB), and the Animal Health Service of the State of Rondônia (IDARON). The field work was performed by IDARON staff, from June 2009 to March 2010, after being trained to standardize the procedures.

In order to characterize regional differences in epidemiological parameters of bovine tuberculosis, the State of Rondônia was divided into three regions, considering the livestock production systems, managing practice, herd size, and trade systems. This division also considered the operational and logistic capacity of the IDARON to perform the fieldwork, based on its seven regional offices. A map of the regions was made in ArcGIS 10.0. software.

In each region, a cross sectional study was performed to estimate the prevalence of bovine 
tuberculosis at herd and animal levels, using a two-stage sampling method. In the first stage, a pre-determined number of farms with reproduction activity was randomly selected (primary sampling units). In the second stage, a pre-determined number of bovine females older than two years of age was randomly selected (secondary sampling units).

In farms were there were more than one individual herd, the biggest and economically more important, in which the animals were submitted to the same managing procedures, i.e. under the same risk factors, was chosen. The choice of the primary sampling units was based on the official farm registry database. If a selected farm could not be visited by IDARON staff, a new one in the vicinity and with the same characteristics was chosen as replacement. The number of selected farms per region was estimated by the simple random sample formula proposed by Thrusfield (2007) and Noordhuizen et al. (1997):

$$
N=Z_{\alpha}{ }^{2} * P *(1-P) / d^{2}
$$

where $N$ denotes the sample size, $Z_{\alpha}$ is the normal distribution value for the confidence level of $95 \%$, $P$ is the expected prevalence $(20 \%)$, and $d$ is the absolute error (5\%).

The choice of the secondary sampling units aimed at the appropriate classification of a farm as positive or negative for tuberculosis. To achieve this, we have used the herd sensitivity and specificity concept (DOHOO et al., 2003). The values for sensitivity and specificity for the test protocol were $80 \%$ and $99.5 \%$, respectively (FLETCHER et al., 1988 ), and $20 \%$ for the expected prevalence. The calculations were made using the Herdacc version 3 , and the selected sample size was the one that allowed herd sensitivity and specificity above $90 \%$. Thus, in farms with at least 99 females older than two years of age, 20 animals were sampled, and in farms with more than 99 females older than two years of age, 40 animals were selected. If the selected herd was smaller than the required sample, all animals were sampled. The choice of females was casual systematic.

To exclude dubious results by the end of the study, those animals with inconclusive results were reexamined with the same diagnostic procedure in a minimum interval of 60 days. All animals that tested positive were euthanized. The occurrence of one animal with a positive result was enough to classify the properties with up to 20 animals tested as an infected. For those, which have tested 40 animals, it took at least two positive animals to declare them as an infected.

\section{Test protocol}

The comparative cervical tuberculin test was used according to the Brazilian National Program for the Control and Eradication of Animal Brucellosis and Tuberculosis (MAPA, 2006). Tested animals were separated from the herd for 72 hours, when the results were read. Animals with inconclusive results were retested 60 days after the first test. If the second test result was inconclusive or positive, the animal was considered positive, according to what is established in the National Program (MAPA, 2006).

\section{Estimation of prevalence}

For each region and throughout the state, the prevalence of infected herds and animals for bovine tuberculosis were obtained. The prevalence of infected herds within each region was also stratified by the type of farming. The apparent prevalence and confidence intervals calculations were performed as recommended by Dean et al. (1996). Calculations referring to the prevalence of infected herds and animals in the state and the animal prevalence within the regions were performed in weighted form (DOHOO et al., 2003). The weight of each property in calculating the prevalence of infected herds in the state was given as follows: 


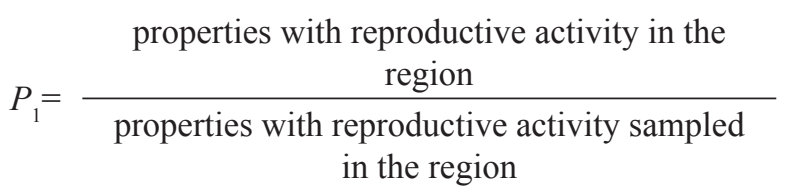

The weight of each animal in the calculation of the prevalence of animals in the state was given by:

$$
\begin{gathered}
P_{2}=\frac{\text { cows } \geq 24 \text { months in the property }}{\text { cows } \geq 24 \text { months sampled in the property }} \times \\
\text { cows } \geq 24 \text { months in the region }
\end{gathered}
$$
cows $\geq 24$ months sampled in the region

In the expression above, the first term refers to the weight of each animal in the calculation of animal prevalence within regions. The calculations were performed with the SPSS program, version 20.

\section{Risk factor analysis}

In each sampled farm, a questionnaire was applied in order to generate data about its managing practices. All information generated in the field and in the laboratory was inserted in a database.

In this cross sectional study, risk factors such as production system (meat, milk, mixed), raising system (extensive, any degree of confinement), cattle breeds, number of cows older than two years of age, total herd size, presence of other domesticated species, presence of wild species, animal trade, tuberculosis testing prior to incorporation in the herd, slaughter in the farm, pasture rent, common pastures, flooded pastures, and veterinary assistance were assessed, according to Marangon et al.
(1998) and Skuce et al. (2012). These variables were organized in an increasing risk scale. When necessary, a recategorization was made. The least risk category was always considered as baseline for comparisons with the other categories. Quantitative variables were categorized using the third quartile as cut point.

An exploratory univariate analysis was made using chi-square $\left(\chi^{2}\right)$, or Fischer exact test was made with all variables, considering the whole State. Those below significance level of $20 \%$ were selected to a multivariate analysis using logistic regression. In the second step, the significance level was $5 \%$. All calculations were made in SPSS 9.0 and EpiInfo 7.0 software.

In order to check if the variables were correlated, a Spearman correlation test was performed. If two variables were correlated, the one that was less associated with the dependent variable was excluded from the multivariate analysis. The significance level for this test was $5 \%$.

\section{Results}

The State of Rondônia was divided into three regions (Figure 1). In Tables 1 and 2 are presented the prevalence at herd and at animal levels, respectively, in the regions and in the whole State. There is no difference in the observed prevalence of tuberculosis-positive farms among regions. There is also no difference in the observed prevalence of tuberculosis-positive animals among regions.

In Table 3 are presented the results from the univariate analysis, showing risk factors with $p<$ 0.20 and, in Table 4, the multivariate model. 
Figure 1. Map of the State of Rondônia showing the regions.

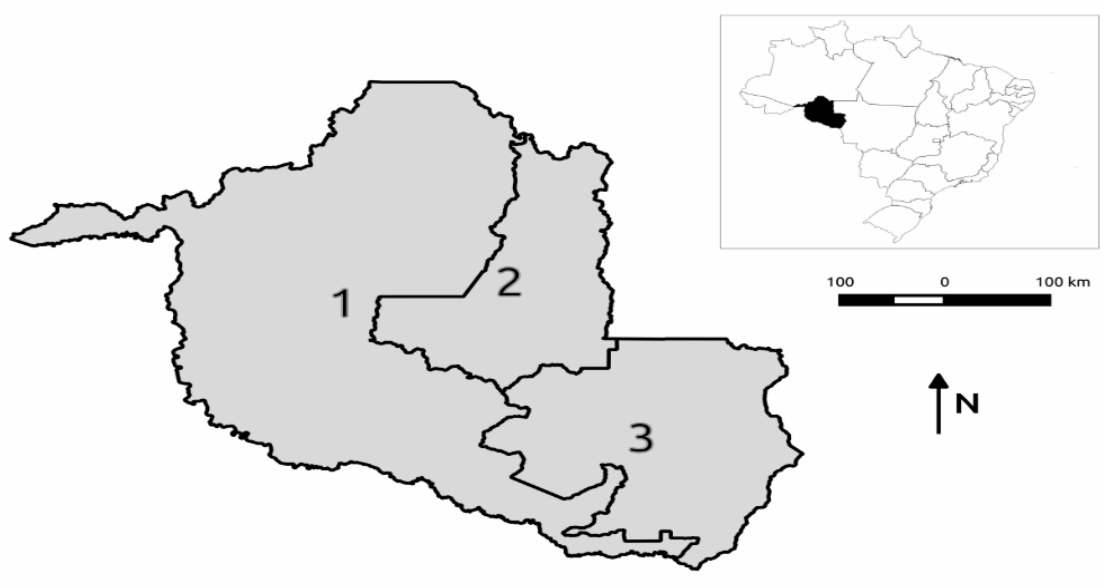

Table 1. Apparent prevalence of tuberculosis-positive farms in the State of Rondônia.

\begin{tabular}{cccccc}
\hline Regions & $\begin{array}{c}\text { Farms with } \\
\text { reproductive } \\
\text { activities }\end{array}$ & Sampled farms & $\begin{array}{c}\text { Tuberculosis } \\
\text { positive farms }\end{array}$ & Prevalence & $\begin{array}{c}95 \% \text { confidence } \\
\text { interval (CI) }\end{array}$ \\
\hline 1 & 25,761 & 296 & 5 & 1.7 & $0.7-4.0$ \\
2 & 25,706 & 299 & 9 & 3.0 & $1.6-5.7$ \\
3 & 23,148 & 309 & 7 & 2.3 & $1.1-4.7$ \\
\hline Total & 74,615 & 904 & 21 & 2.33 & $1.52-3.52$ \\
\hline
\end{tabular}

Table 2. Apparent prevalence of tuberculosis-positive bovine females older than two years of age in the State of Rondônia.

\begin{tabular}{lrrrrr}
\hline Regions & $\begin{array}{c}\text { Bovine females } \\
\text { older than two } \\
\text { years of age }\end{array}$ & Serum samples & $\begin{array}{c}\text { Tuberculosis } \\
\text { positive animals }\end{array}$ & Prevalence & $\begin{array}{c}\text { 95\% confidence } \\
\text { interval (CI) }\end{array}$ \\
\hline 1 & $1,867,197$ & 6,741 & 8 & 0.12 & $0.04-0.41$ \\
2 & $1,418,816$ & 6,576 & 10 & 0.15 & $0.07-0.33$ \\
3 & $1,391,430$ & 6,323 & 8 & 0.08 & $0.04-0.18$ \\
\hline Total & $4,677,443$ & 19,640 & 26 & 0.12 & $0.06-0.25$ \\
\hline
\end{tabular}


Table 3. Univariate analysis of the risk factors for bovine tuberculosis in the State of Rondônia.

\begin{tabular}{|c|c|c|c|}
\hline Variable & $\begin{array}{l}\text { Exposed/positive } \\
\text { farms }\end{array}$ & $\begin{array}{c}\text { Exposed/negative } \\
\text { farms }\end{array}$ & $p$ \\
\hline \multicolumn{4}{|l|}{ Acquisition of animals } \\
\hline No & $5 / 8$ & $404 / 438$ & 0.022 \\
\hline Yes & $3 / 8$ & $34 / 438$ & \\
\hline \multicolumn{4}{|l|}{ Marsupial presence } \\
\hline No & $7 / 21$ & $469 / 883$ & 0.073 \\
\hline Yes & $14 / 21$ & $414 / 883$ & \\
\hline \multicolumn{4}{|l|}{ Raising system } \\
\hline Extensive & $19 / 21$ & $846 / 867$ & 0.100 \\
\hline Any degree of confinement & $2 / 21$ & $21 / 867$ & \\
\hline \multicolumn{4}{|l|}{ Cow milking } \\
\hline No & $1 / 20$ & $162 / 834$ & 0.148 \\
\hline Yes & $19 / 20$ & $672 / 834$ & \\
\hline \multicolumn{4}{|l|}{ Presence of wild animals } \\
\hline No & $2 / 21$ & $210 / 883$ & 0.190 \\
\hline Yes & $19 / 21$ & $673 / 883$ & \\
\hline
\end{tabular}

bTB: bovine tuberculosis.

Table 4. Final multivariate model of the risk factors for bovine tuberculosis in the State of Rondônia.

\begin{tabular}{lccccc}
\hline Variable & Cases & Exposed & $p$ & Odds ratio & 95\% confidence interval \\
\hline Acquisition of animals & 8 & 37 & 0.009 & 7.1 & $1.6-31.1$ \\
\hline $\mathrm{r}^{2}=7.3 \%$. & & & & &
\end{tabular}

\section{Discussion}

The herd prevalence of bovine tuberculosis in the State of Rondônia was $2.33 \%$ [1.52; 3.55] (Table 1), statistically equal to Paraná, Bahia, Rio Grande do Sul, Mato Grosso, Mato Grosso do Sul, Goiás, Pernambuco, Distrito Federal, and Minas Gerais, higher than Santa Catarina, and lower than São Paulo and Espírito Santo (BAHIENSE et al., 2016; BARBIERI et al., 2016; DIAS et al., 2016; GALVIS et al., 2016; GUEDES et al., 2016; LIMA et al., 2016; NÉSPOLI et al., 2016; QUEIROZ et al., 2016; RIBEIRO et al., 2016; ROCHA et al., 2016; SILVA et al., 2016; VELOSO et al., 2016). Tuberculosis-infected herds are homogeneously spread among the regions of the state (Table 2), and the prevalence of animals followed the same distribution (Table 3).
The classic risk factor for bovine tuberculosis is the introduction of animals with unknown sanitary conditions (DE LA CRUZ et al., 2014; DOMMERGUES et al., 2012; GILBERT et al., 2005; GRISI-FILHO et al., 2011). In fact, the only risk factor of bovine tuberculosis in Rondônia was the acquisition of animals.

\section{Conclusion}

The State of Rondônia should implement a surveillance system to detect bTB-infected herds to certify them as bTB-free. Moreover, an efficient health education program to inform farmers to test replacement animals for bTB prior to introduction in their herds should also be implemented. 


\section{Acknowledgements}

The authors acknowledge the logistical and financial support from MAPA, IDARON, CNPq and FAPESP.

\section{References}

BAHIENSE, L.; ÁVILA, L. N. de; BAVIA, M. E.; AMAKU, M.; DIAS, R. A.; GRISI-FILHO, J. H. H.; FERREIRA, F.; TELLES, E. O.; GONÇALVES, V. S. P.; HEINEMANN, M. B.; FERREIRA NETO, J. S. Prevalence and risk factors for bovine tuberculosis in the State of Bahia, Brazil. Semina: Ciências Agrárias, Londrina, v. 37, n. 5, p. 3549-3560, 2016. Suplemento 2.

BARBIERI, J. M.; OLIVEIRA, L. F.; DORNELES, E. M. S.; MOTA, A. L. A. A.; GONÇALVES, V. S. P.; MALUF, P. P.; FERREIRA NETO, J. S.; FERREIRA, F.; DIAS, R. A.; TELLES, E. O.; GRISI-FILHO, J. H. H.; HEINEMANN, M. B.; AMAKU, M.; LAGE, A. P. Epidemiological status of bovine tuberculosis in the state of Minas Gerais, Brazil, 2013. Semina: Ciências Agrárias, Londrina, v. 37, n. 5, p. 3531-3548, 2016. Suplemento 2.

DE LA CRUZ, M. L.; PEREZ, A.; BEZOS, J.; PAGES, E.; CASAL, C.; CARPINTERO, J.; ROMERO, B.; DOMINGUEZ, L.; BARKER, C. M.; DIAZ, R.; ALVAREZ, J. Spatial dynamics of bovine tuberculosis in the Autonomous Community of Madrid, Spain (20102012). PLoS One, San Francisco, v. 9, n. 12, p. e115632, 2014.

DEAN, A. G.; DEAN, J. A.; COULOMBIER, D.; BRENDEL, K. A.; SMITH, D. C.; BURTON, A. H.; DICKER, R. C.; SULLIVAN, K.; FAGAN, R. F.; ARNER, T. G. Epi Info, version 6: a word processing, database, and statistics program for public health on IBM-compatible microcomputers. Atlanta: Centers for Disease Control and Prevention, 1996. 595 p.

DIAS, R. A.; STANOJLOVIC, F. M. U.; BELCHIOR, A. P. C.; FERREIRA, R. S.; GONÇALVES, R. C.; AGUIAR, R. S. C. B.; SOUSA, P. R.; SANTOS, A. M. A.; AMAKU, M.; FERREIRA, F.; TELLES, E. O.; GRISI-FILHO, J. H. H.; GONÇALVES, V. S. P.; HEINEMANN, M. B.; FERREIRA NETO, J. S. Prevalence and risk factors for bovine tuberculosis in the state of São Paulo, Brazil. Semina: Ciências Agrárias, Londrina, v. 37, n. 5, p. 3673-3684, 2016. Suplemento 2.

DOHOO, I.; MARTIN, W.; STRYHN, H. Veterinary epidemiologic research. Charlottetown: Atlantic Veterinary College, 2003. 704 p.
DOMINGO, M.; VIDAL, E.; MARCO, A. Pathology of bovine tuberculosis. Research in Veterinary Science, Oxford, v. 97, p. S20-S29, 2014. Supplement.

DOMMERGUES, L.; RAUTUREAU, S.; PETIT, E.; DUFOUR, B. Network of contacts between cattle herds in a French area affected by bovine tuberculosis in 2010. Transboundary and Emerging Diseases, Malden, v. 59, n. 4, p. 292-302, 2012.

FLETCHER, R. H.; FLETCHER, S. W.; WAGNER, E. H. Clinical epidemiology: the essentials. $2^{\text {th }}$ ed. Baltimore: Williams \& Wilkins, 1988. 260 p.

GALVIS, J. O. A.; GRISI-FILHO, J. H. H; COSTA, D.; SAID, A. L. P. R.; AMAKU, M.; DIAS, R. A.; FERREIRA, F.; GONÇALVES, V. S. P.; HEINEMANN, M. B.; TELLES, E. O.; FERREIRA NETO, J. S. Epidemiologic characterization of bovine tuberculosis in the state of Espírito Santo, Brazil. Semina: Ciencias Agrárias, Londrina, v. 37, n. 5, p. 3567-3578, 2016. Suplemento 2.

GILBERT, M.; MITCHELL, A.; BOURN, D.; MAWDSLEY, J.; CLIFTON-HADLEY, R.; WINT, W. Cattle movements and bovine tuberculosis in Great Britain. Nature, London, v. 435, n. 7041, p. 491-496, 2005.

GRISI-FILHO, J. H. H.; ROSALES, C. A. R.; FERREIRA, F.; AMAKU, M.; DIAS, R. A.; FERREIRA NETO, J. S. Análise epidemiológica das condenações de bovinos por tuberculose em abatedouros do Estado de São Paulo. Arquivos do Instituto Biológico, São Paulo, v. 78, n. 2, p. 175-181, 2011.

GUEDES, I. B.; BOTTENE, I. F. N.; MONTEIRO, L. A. R. C.; LEAL FILHO, J. M.; HEINEMANN, M. B.; AMAKU, M.; GRISI-FILHO, J. H. H.; DIAS, R. A.; FERREIRA, F.; TELLES, E. O.; GONÇALVES, V. S. P.; FERREIRA NETO, J. S. Prevalence and risk factors for bovine tuberculosis in the state of Mato Grosso do Sul, Brazil. Semina: Ciências Agrárias, Londrina, v. 37, n. 5, p. 3579-3588, 2016. Suplemento 2.

LIMA, P. B.; NASCIMENTO, D. L.; ALMEIDA, E. C.; PONTUAL, K. A. Q.; AMAKU, M.; DIAS, R. A.; FERREIRA, F.; GONÇALVES, V. S. P.; TELLES, E. O.; GRISI-FILHO, J. H. H.; HEINEMANN, M. B.; SILVA, J. C. R.; FERREIRA NETO, J. S. Epidemiological situation of bovine tuberculosis in the state of Pernambuco, Brazil. Semina: Ciências Agrárias, Londrina, v. 37, n. 5, p. 3601-3610, 2016. Suplemento 2.

MARANGON, S.; MARTINI, M.; DALLA POZZA, M.; FERREIRA NETO, J. S. A case-control study on bovine tuberculosis in the Veneto region, Italy. Preventive Veterinary Medicine, Colorado, v. 34, n. 2, p. 87-95, 1998. 
MINISTÉRIO DA AGRICULTURA, PECUÁRIA E ABASTECIMENTO - MAPA. Programa Nacional de Controle e Erradicação da Brucelose e Tuberculose. Brasília: MAPA, 2006. Disponível em: <http://www. agricultura.gov.br>. Acesso em: 22 mar. 2016.

NÉSPOLI, J. M. B.; NEGREIROS, R. L.; AMAKU, M.; DIAS, R. A.; FERREIRA, F.; TELLES, E. O.; HEINEMANN, M. B.; GRISI-FILHO, J. H. H.; GONÇALVES, V. S. P.; FERREIRA NETO, J. S. Epidemiological situation of bovine tuberculosis in the state of Mato Grosso, Brazil. Semina: Ciências Agrárias, Londrina, v. 37, n. 5, p. 3589-3600, 2016. Suplemento 2.

NOORDHUIZEN, J. P. T. M.; FRANKENA, K.; HOOFD, C. M. Application of quantitative methods in veterinary epidemiology. Wageningen: Wageninggen Press, 1997. 445 p.

QUEIROZ, M. R.; GROFF, A. C. M.; SILVA, N. S.; GRISI-FILHO, J. H. H.; AMAKU, M.; DIAS, R. A.; TELLES, E. O.; HEINEMANN, M. B.; FERREIRA NETO, J. S.; GONÇALVES, V. S. P. FERREIRA, F. Epidemiological status of bovine tuberculosis in the state of Rio Grande do Sul, Brazil. Semina: Ciências Agrárias, Londrina, v. 37, n. 5, p. 3647-3658, 2016. Suplemento 2.

RIBEIRO, L. A.; GONÇALVES, V. S. P.; FRANCISCO, P. F. C.; MOTA, A. L. A. A.; NASCIMENTO, G. T.; LICURGO, J. B.; FERREIRA, F.; GRISI-FILHO, J. H. H.; FERREIRA NETO, J. S.; AMAKU, M.; DIAS, R. A.; TELLES, E. O.; HEINEMANN, M. B.; BORGES, J. R. J. Epidemiological status of bovine tuberculosis in the Federal District of Brazil. Semina: Ciências Agrárias, Londrina, v. 37, n. 5, p. 3561-3566, 2016. Suplemento 2.

ROCHA, W. V.; JAYME, V. S.; MOTA, A. L. A. A.; BRITO, W. M. E. D; PIRES, G. R. C; GRISI-FILHO, J. H. H; DIAS, R. A.; AMAKU, M.; TELLES, E. O.; HEINEMANN, M. B.; FERREIRA, F.; FERREIRA NETO, J. S.; GONÇALVES, V. S. P.; Prevalence and herd-level risk factors of bovine tuberculosis in the State of Goiás, Brazil. Semina: Ciências Agrárias, Londrina, v. 37, n. 5, p. 3625-3628, 2016. Suplemento 2.

SILVA, M. C. P.; GONÇALVES, V. S. P.; MOTA, A. L. A. A.; KOLODA, M.; FERREIRA NETO, J. S.; GRISIFILHO, J. H. H; DIAS, R. A.; AMAKU, M.; TELLES, E. O.; FERREIRA, F.; HEINEMANN, M. B.; ALFIERI, A. A.; MULLER, E. E. Prevalence and herd-level risk factors for bovine tuberculosis in the state of Paraná, Brazil. Semina: Ciências Agrárias, Londrina, v. 37, n. 5, p. 3611-3624, 2016. Suplemento 2.

SKUCE, R. A.; ALLEN, A. R.; MCDOWELL, S. W. J. Herd-level risk factors for bovine tuberculosis: a literature review. Veterinary Medicine International, v. 2012, Article ID 621210, p. 1-10, 2012. Available at: $<$ http://www.hindawi.com/journals/vmi/2012/621210/ abs/>. Accessed at: 20 june 2015.

THRUSFIELD, M. Veterinary epidemiology. $3^{\text {th }}$ ed. Oxford: Blackwell Science, 2007. 610 p.

VELOSO, F. P.; BAUMGARTEN, K. D.; MOTA, A. L. A. A.; FERREIRA, F.; FERREIRA NETO, J. S.; GRISI-FILHO, J. H. H.; DIAS, R. A.; AMAKU, M.; TELLES, E. O.; HEINEMANN, M. B.; GONÇALVES, V. S. P. Prevalence and herd-level risk factors of bovine tuberculosis in the State of Santa Catarina, Brazil. Semina: Ciências Agrárias, Londrina, v. 37, n. 5, p. 3659-3672, 2016. Suplemento 2.

ZINSSTAG， J.; SCHELLING， E.; ROTH， F.; KAZWALA, R. Economics of bovine tuberculosis. In: THOEN, C. O.; STEELE, J. H.; GILSDORF, M. J. (Ed.). Mycobacterium bovis infection in animals and humans. $2^{\text {nd }}$ ed. Ames: Blackwell Publishing, 2006. p. 68-83.

WORLD ORGANIZATION FOR ANIMAL HEALTH OIE. World animal health information database interface. Paris: OIE, 2015. Available at: <http://www.oie.int/ wahis/public.php?page=home $>$. Accessed at: 22 mar. 2016. 